\title{
Fire weather effects on flammability of indigenous and invasive alien plants in coastal fynbos and thicket shrublands (Cape Floristic Region)
}

\author{
Samukelisiwe T Msweli ${ }^{\text {Equal first author, } 1}{ }^{\text {, Alastair J Potts }}{ }^{2}$, Herve Fritz ${ }^{3,4}$, Tineke Kraaij ${ }^{\text {Corresp. Equal first author, } 1}$ \\ ${ }^{1}$ School of Natural Resource Management, Nelson Mandela University, George, Western Cape, South Africa \\ 2 Botany Department, Nelson Mandela University, Port Elizabeth, Eastern Cape, South Africa \\ 3 REHABS International Research Laboratory, CNRS-Université de Lyon1-Nelson Mandela University, George, South Africa \\ 4 Sustainability Research Unit, Nelson Mandela University, George, Western Cape, South Africa \\ Corresponding Author: Tineke Kraaij \\ Email address: tineke.kraaij@mandela.ac.za
}

Background. Globally, and in the Cape Floristic Region of South Africa, extreme fires have become more common in recent years. Such fires pose societal and ecological threats and have inter alia been attributed to climate change and modification of fuels due to alien plant invasions. Understanding the flammability of different types of indigenous and invasive alien vegetation is essential to develop fire risk prevention and mitigation strategies. We assessed the flammability of 30 species of indigenous and invasive alien plants commonly occurring in coastal fynbos and thicket shrublands in relation to varying fire weather conditions.

Methods. Fresh plant shoots were sampled and burnt experimentally across diverse fire weather conditions to measure flammability in relation to fire weather conditions, live fuel moisture, fuel load and vegetation grouping (fynbos, thicket, and invasive alien plants). Flammability measures considered were: burn intensity, completeness of burn, time-to-ignition, and the likelihood of spontaneous ignition. We also investigated whether the drying of plant shoots (simulating drought conditions) differentially affected the flammability of vegetation groups.

Results. Fire weather conditions enhanced all measures of flammability, whereas live fuel moisture reduced burn intensity and completeness of burn. Live fuel moisture was not significantly correlated with fire weather, suggesting that the mechanism through which fire weather enhances flammability is not fuel moisture. It furthermore implies that the importance of live fuel moisture for flammability of evergreen shrublands rests on inter-specific and inter-vegetation type differences in fuel moisture, rather than short-term intra-specific fluctuation in live fuel moisture in response to weather conditions. Fuel load significantly increased burn intensity, while reducing ignitability. Although fire weather, live fuel moisture, and fuel load had significant effects on flammability measures, vegetation and species differences accounted for most of the variation. Flammability was generally highest in invasive alien plants, intermediate in fynbos, and lowest in thicket. Fynbos ignited rapidly and burnt completely, whereas thicket was slow to ignite and burnt incompletely. Invasive alien plants were slow to ignite, but burnt with the highest intensity, potentially due to volatile organic composition. The drying of samples resulted in increases in all measures of flammability that were comparable among vegetation groups. Flammability, and by implication fire risk, should thus not increase disproportionately in one vegetation group compared to another under drought conditions - unless the production of dead fuels is disproportionate among vegetation groups. Thus, we suggest that the dead:live fuel ratio is a potentially useful indicator of flammahility of everareen shrublands and that proxies for this ratio need to be 
investigated for incorporation into fire danger indices. 
1 Fire weather effects on flammability of indigenous and invasive alien plants in

2 coastal fynbos and thicket shrublands (Cape Floristic Region)

3

4

5

6

\section{7}

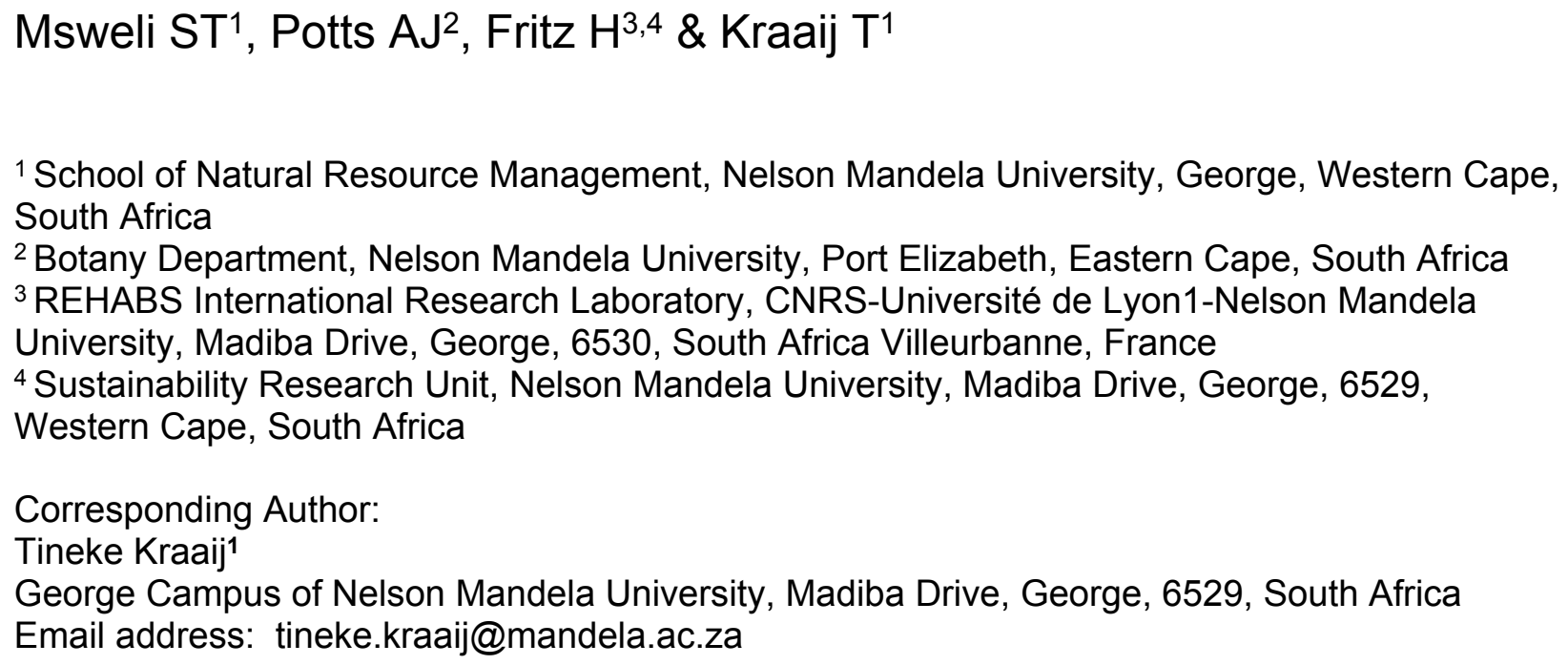

\section{Abstract}

Background. Globally, and in the Cape Floristic Region of South Africa, extreme fires have become more common in recent years. Such fires pose societal and ecological threats and have inter alia been attributed to climate change and modification of fuels due to alien plant invasions. Understanding the flammability of different types of indigenous and invasive alien vegetation is essential to develop fire risk prevention and mitigation strategies. We assessed the flammability of 30 species of indigenous and invasive alien plants commonly occurring in coastal fynbos and thicket shrublands in relation to varying fire weather conditions.

Methods. Fresh plant shoots were sampled and burnt experimentally across diverse fire weather conditions to measure flammability in relation to fire weather conditions, live fuel moisture, fuel load and vegetation grouping (fynbos, thicket, and invasive alien plants). Flammability measures considered were: burn intensity, completeness of burn, time-to-ignition, and the likelihood of spontaneous ignition. We also investigated whether the drying of plant shoots (simulating drought conditions) differentially affected the flammability of vegetation groups.

Results. Fire weather conditions enhanced all measures of flammability, whereas live fuel moisture reduced burn intensity and completeness of burn. Live fuel moisture was not significantly correlated with fire weather, suggesting that the mechanism through which fire weather enhances flammability is not fuel moisture. It furthermore implies that the importance of 
38 live fuel moisture for flammability of evergreen shrublands rests on inter-specific and intervegetation type differences in fuel moisture, rather than short-term intra-specific fluctuation in live fuel moisture in response to weather conditions. Fuel load significantly increased burn intensity, while reducing ignitability. Although fire weather, live fuel moisture, and fuel load had significant effects on flammability measures, vegetation and species differences accounted for most of the variation. Flammability was generally highest in invasive alien plants, intermediate in fynbos, and lowest in thicket. Fynbos ignited rapidly and burnt completely, whereas thicket was slow to ignite and burnt incompletely. Invasive alien plants were slow to ignite, but burnt with the highest intensity, potentially due to volatile organic composition. The drying of samples resulted in increases in all measures of flammability that were comparable among vegetation groups. Flammability, and by implication fire risk, should thus not increase disproportionately in one vegetation group compared to another under drought conditions - unless the production of dead fuels is disproportionate among vegetation groups. Thus, we suggest that the dead:live fuel ratio is a potentially useful indicator of flammability of evergreen shrublands and that proxies for this ratio need to be investigated for incorporation into fire danger indices.

53

Keywords: burn intensity, completeness of burn, drought, fire danger indices, fire risk, fuel load, live fuel moisture, time-to-ignition, spontaneous ignition, wildland-urban interface

56

\section{Introduction}

58 Flammability is the ability of vegetation (fuel) to burn (Fernandes and Cruz, 2012; Gill and Zylstra, 2005) and is a measure of fire behavior (fire intensity/severity) used in vegetation fire risk mitigation studies (Keeley, 2009). Vegetation flammability may result from climatic and weather effects (Bond and Midgley, 1995; Mutch, 1970; Snyder, 1984). For example, in arid areas, dryness limits fuel accumulation and fires follow episodic rain, whereas in temperate areas, fuel loads are not limiting but fires follow the drying of those fuels (Bradstock, 2010; Pausas and Bradstock, 2007), however dry conditions may also result in an increase in fire risk caused by the availability of dried fuels (Piñol et al., 1998). Fire-prone vegetation groups may fire-dependent communities (Bond and Midgley, 1995). Correspondingly, species with high flammability traits may burn intensely, such that itself and the neighbour die, thereby facilitating recruitment - the 'kill thy neighbour' hypothesis (Bond and Midgley, 1995). Flammability traits may thus provide resilience associated with fire tolerance (Bond and Midgley, 1995; Calitz et al., 2015). Fire is accordingly one of the main determining factors of the ecology and distribution of 
72 ecosystems of the world, and is important for maintaining plant diversity (Bond, 1997; Bond et 73 al., 2003; Bond and Keeley, 2005).

$74 \quad$ Flammability is also affected by weather conditions (Bond, 1997; Keeley and Syphard, 75 2017). Fire danger indices - based on ambient temperature, relative humidity, wind speed, and 76 rainfall - are commonly used to rate the fire-proneness of weather conditions (Dowdy et al., 77 2009; Noble et al., 1980; Sirca et al., 2018). Flammability is also influenced by fuel properties 78 such as the amount of flammable plant material (fuel load), packing ratio and chemical 79 composition (Brooks et al., 2004; Burger and Bond, 2015; Curran et al., 2017). For instance, 80 greater fuel loads or volatile substances can increase fire intensity (Baeza et al., 2002; Saura81 Mas et al., 2010).

82 Globally, extreme fires have become more common in recent years. Examples include 83 the shrublands of California, Australia, Europe (Montenegro et al., 2004; San-Miguel-Ayanz et 84 al., 2013), and more recently, South Africa (Kraaij et al., 2018). These fires have been 85 accredited to the combinations of climate change (in the form of weather conditions more 86 conducive to fire and extended droughts), increased ignitions, expanded wildland-urban 87 interface areas linked to increasing human populations, and changes in fuels that are often 88 human-induced (Archibald et al., 2008; Montenegro et al., 2004; Syphard et al., 2017; Turco et 89 al., 2017; van Wilgen, 1984). Fuels accumulate far beyond normal levels when humans suppress fires to safeguard assets, and due to invasion by invasive alien plants (hereafter IAPs) (Kraaij et al., 2018; Radeloff et al., 2005; Scott et al., 1998). The IAPs may affect flammability by altering the fuel structure, fuel distribution (horizontal or vertical fuel continuity), live fuel moisture, chemical contents and fuel load (Brooks et al., 2004; Davies and Nafus, 2013; Richardson and van Wilgen, 2004). Extreme fires are also known to occur in shrublands after severe droughts due to the increase of dead ( dry) to live fuel ratios (Keeley et al., 2012; Keeley and Syphard, 2017; Kraaij et al., 2018).

Along the southern Cape coast of South Africa, fynbos and thicket shrublands occur interspersed (Supplemental Figure S1) despite displaying different fire dynamics and fuel structural traits (Campbell et al., 1981; Moll et al., 1984). Fynbos ecosystems commonly support fires that consume surface and canopy fuels and comprise species that readily burn to open recruitment opportunities (gaps) post-fire (Buhk et al., 2007; Deacon et al., 1992). However, thicket mostly does not exhibit high flammability traits (Calitz et al., 2015), and recruitment from seed largely occurs in inter-fire periods (Cowling et al., 1997; Pierce and Cowling, 1984). In 2017, extreme fires occurred in this region around the town of Knysna which burnt indigenous 105 fynbos and thicket vegetation and further caused extensive damage to commercial plantations 
106 and residential properties (Fares et al., 2017; Kraaij et al., 2018). The extreme nature of these

107 fires has been attributed to extensive IAP fuels, an expansive wildland-urban interface area, an

108 unprecedented regional drought preceding the fires which likely greatly increased litter fuels in

109 thicket, fynbos and stands of IAPs, and very high fire danger weather conditions at the time of

110 the fires (Kraaij et al., 2018; Preston, 2017). The 2017 Knysna fires called for improved

111 understanding of potential differences in flammability among vegetation groups, including IAPs

112 occurring in this region. An analysis of satellite image derived proxies for burn severity showed it

113 to be higher, but completeness of burn lower, in IAPs than in indigenous fynbos and thicket

114 vegetation (Kraaij et al. 2018). However, the findings have not been verified with field

115 observations (Kraaij et al., 2018). Other studies have experimentally compared the flammability

116 of species from several biomes (both fire-prone and fire-resistant) (Burger and Bond, 2015;

117 Calitz et al., 2015), however, no study has compared the flammability of indigenous vegetation 118 with that of IAPs, nor under varying fire weather conditions.

119 The primary aim of our study was to compare the flammability of live plant material

120 amongst three vegetation groups - IAPs, fynbos, and thicket - and under varying fire weather

121 conditions. Flammability measures considered were burn intensity, completeness of burn, and

122 ignitability (time-to-ignition and likelihood of spontaneous ignition), while fuel traits considered

123 were live fuel moisture and fuel load. A secondary aim was to assess the flammability of

124 partially dried plant material as a crude proxy for drought effects, to ascertain whether drying of

125 fuels ( drought) would differentially affect the flammability of the vegetation groups of interest.

126 Study results will inform fire risk management in the southern Cape landscapes and elsewhere

127 with similar fuel traits and characteristics.

128

\section{Materials \& Methods}

130 Study area

131 This study was conducted along the southern Cape coast of South Africa within the Cape

132 Floristic Region close to the city of George $\left(33.964^{\circ} \mathrm{S}, 22.534^{\circ} \mathrm{E}\right)$. The climate is moderated by

133 the maritime influence with average minimum and maximum temperatures ranging from $7-19^{\circ} \mathrm{C}$

134 in June and $15-26^{\circ} \mathrm{C}$ in January an annual average rainfall of approximately $800 \mathrm{~mm}$ throughout

135 the year (Bond, 1981). The area experiences weather conditions suitable for fires at any time of

136 the year and fires are often associated with hot, dry katabatic ('berg') winds (Kraaij et al., 2013;

137 van Wilgen, 1984).

138 The vegetation of the study area is classified as Southern Cape Dune Fynbos (Mucina

139 and Rutherford, 2006; Pierce and Cowling, 1984), which consists of medium-dense

Peer] reviewing PDF | (2020:04:48231:1:1:NEW 10 Sep 2020) 
140 sclerophyllous fynbos ( fine-leaved) shrublands up to $2 \mathrm{~m}$ in height, interspersed with dense

141 clumps of subtropical mesophyllous thicket shrubs or trees up to $4 \mathrm{~m}$ in height (Supplemental

142 Figure S1) (Campbell et al., 1981; Kraaij et al., 2011; Pierce and Cowling, 1984). Both fynbos

143 and thicket are evergreen. Fynbos shrublands are fire-prone and flammable while smaller areas

144 of thicket vegetation seldom burn (Geldenhuys, 1994). The persistence of fynbos-thicket

145 mosaics requires fire at appropriate intervals (15-25 years) since thicket becomes dominant in

146 the prolonged absence of fire (Kraaij and van Wilgen, 2014; Strydom et al., submitted). The

147 area contains extensive invasions of alien shrubs and trees, commonly of the genera Acacia,

148 Eucalyptus, and Pinus, that co-occur with, and potentially replace, the native vegetation

149 (Supplemental Figure S1) (Baard and Kraaij, 2014; van Wilgen et al., 2016).

151 Data collection

152 Live plant samples

153 We experimentally measured the flammability of plant shoots (i.e. plant stems) of species from

154 three vegetation groups, namely IAPs, fynbos, and thicket. Fine fuels such as plant shoots

155 (hereafter samples) are the primary carriers or vectors of fire spread (Murray et al., 2013). Our

156 experiments were thus focused on plant shoots, with one stem constituting one sample.

157 Sampling was done over 21 occasions (February - November 2018) that were specifically

158 selected to represent varying fire weather conditions. On each occasion, we collected two live

159 plant samples of 30 species across three vegetation groups (10 species per vegetation group;

160 details in Supplemental Table S1) common in the study area. One sample was used for

161 flammability experiments, while the other was used for live fuel moisture measurements. For

162 each species, samples of approximately $70 \mathrm{~cm}$ in length that were representative of the fuel

163 structure characteristic of the species were sourced. On each sampling occasion, samples from

164 all 30 species were collected and burnt to ensure that flammability was measured under

165 comparable conditions. Sample collection either started at 9h00 and subsequent burning at

$16612 \mathrm{~h} 00$ or at $11 \mathrm{~h} 00$ and $14 \mathrm{~h} 00$ (respectively) to incorporate additional variation in fire weather

167 conditions. Samples were kept in closed plastic containers after collection prior to burning, and

168 burning was completed within four hours of sample collection to minimise moisture loss. The

169 order in which samples of different species were burnt was also randomised among the different

170 burning occasions to not consistently expose particular species to longer periods of moisture

171 loss prior to burning. For each occasion, the Canadian fire weather index was computed based

172 on the temperature, relative humidity, rainfall (over the past 24 hours), and wind speed (Van

173 Wagner 1987) at the time that burning commenced. This index integrates drought and other 
174 atmospheric effects that are relevant to fire behavior and fuel moisture, and it was shown to be 175 the best performing fire danger index in Mediterranean ecosystems (Sirca et al., 2018). The 176 input weather measures were obtained from a weather station located on the George Campus 177 of Nelson Mandela University ('Saasveld NMMU CW373' on the Vital Weather online platform: 178 www.vitalweather.co.za) where the experimental burning was conducted.

Samples used for flammability were burnt outdoors using an approach similar to that of 180 Calitz et al. (2015) and Curran et al. (2017). Plant flammability was measured using the method 181 and equipment described by Jaureguiberry et al. (2011), the apparatus comprises a metal barrel $182(85 \mathrm{~cm} \times 60 \mathrm{~cm})$ that is horizontally orientated with the top removable half that is used for wind protection (Baeza et al., 2002). The metal barrel is connected to a grill thermometer, removable gas cylinder and a blowtorch (Curran et al., 2017; Jaureguiberry et al., 2011). Each sample was placed on the barrel cavity grill to pre-heat at $230^{\circ} \mathrm{C}$ for two minutes to imitate the heating and drying effect of an approaching fire. If the samples had not spontaneously ignited within two minutes, it was ignited at the top of the shoot by exposing it to the blow torch for a period of five seconds (Calitz et al., 2015). Advantages of using this apparatus are that it preserves the architectural arrangement of plant material (Jaureguiberry et al., 2011). It further enables a more realistic comparison of relative canopy flammability among species than methods that use only smaller plant components (i.e. twigs or leaves) (Burger and Bond, 2015; Jaureguiberry et al., 192 2011).

Four aspects associated with species-level flammability were measured and recorded (largely after Calitz et al., 2015 and Jaureguiberry et al., 2011). Firstly, burn intensity taken as the maximum temperature (cf. Keeley, 2009) reached by a sample while burning, measured using an infrared thermometer (Major Tech 695; maximum recordable temperature: $800^{\circ} \mathrm{C}$ ) after Jaureguiberry et al. (2011). Secondly, the completeness of burn, calculated as the proportion of the pre-burn wet mass of the samples that was consumed by the fire (mass was measured using an electronic scale). Thirdly, time-to-ignition, measured as the time elapsed between placement of the samples on the grill and spontaneous ignition (appearance of the first flame); samples that required to be ignited with the blow torch were therefore excluded from this measures' dataset. For every sample, we recorded whether it spontaneously ignited within the two minutes (pre-heating duration was consistent as there were many samples) of pre-heating or not, this binomial response comprising the fourth measure termed 'spontaneous ignition'. Live fuel moisture was calculated on a sample shoot similar in dimensions to that of 206 flammability measurements. The fresh material was stored in sealed containers (of known 207 mass) until these were weighed (within less than 3 hours of collection) to obtain wet fuel mass. 
208 Samples were then oven-dried at $80^{\circ} \mathrm{C}$ for 48 hours and weighed again to obtain dry fuel mass 209 (Ruffault et al., 2018; Teie, 2009; Yebra et al., 2019). The live fuel moisture was calculated as 210 the percentage of wet mass comprised of water. Although sample size (shoot length) was 211 standardized, samples nevertheless presented different fuel loads which are directly related to 212 burn intensity (Byram 1959). Thus, dry plant mass was used to represent the variable fuel load.

213 We estimated the dry plant mass of each sample from its pre-burn wet mass and the

214 percentage water content that was calculated for its analogous dried sample.

216 Dried plant samples

217 To investigate whether simulated drought conditions differentially affected the flammability of the 218 vegetation groups, additional samples (similar to that collected for the flammability experiment's 219 live samples described above) were collected and left to dry under ambient conditions, out of 220 direct sunlight, for a minimum of two weeks but not until leaf loss occurred. Sampling was 221 conducted over five occasions (during February - March 2019) of high fire weather conditions.

222 The drying duration was standardized for all species to avoid the loss of leaves since certain 223 plants would drop leaves due to drought stress (Clarke and McCaig, 1982). Flammability

224 experiments and pre-burn estimations of live fuel moisture were undertaken on these dried 225 samples as described above for live (undried) samples.

226

227

Data analysis

228 Live plant samples

229 We assessed flammability (of live samples) in terms of four response variables (burn intensity, 230 completeness of burn, time-to-ignition, and spontaneous ignition) respectively, in relation to the 231 predictor variables (i) fire weather (continuous), (ii) live fuel moisture (continuous), (iii) fuel load 232 (dry plant mass; continuous), (iv) vegetation groups (IAPs, fynbos, thicket; categorical) and (v) 233 species (30 species; categorical) using generalized linear mixed-effects models (Bates, 2010; 234 O'Hara, 2009) using the Ime4 package (Bates, 2010) in the open-source R software version 235 3.6.1 (R Development Core Team 2019). Detailed species-level comparisons were not the 236 primary focus of the study and species was therefore included as a random factor, whereas the 237 other predictor variables were included as fixed factors. To test for potential collinearity between 238 fire weather and live fuel moisture, we ran the Spearman-rank correlation test for each 239 respective species. It showed that these variables were not significantly correlated (see Results) 240 and could both be retained in subsequent analyses. Burn intensity was log-transformed (to 241 correct right-skewed distribution), completeness of burn arcsine-transformed (as it was 
242 expressed as proportions), time-to-ignition square root-transformed (to correct left-skewed

243 distribution), and spontaneous ignition assessed using logistic regression (binomial family, logit

244 link function) (formulae provided in Supplemental Table S2). Subsequently, Type II Wald chi-

245 square test (Hastie and Pregibon, 1992) was computed to determine the significance of fixed

246 factors on the specific models. We incorporated the scale function to the generalized linear

247 mixed-effects models and logistic regression model (using transformed data) to standardize

248 variables of different scales and obtain the relative influence of fixed factors (Becker et al.,

249 1988).

250

251 Dried plant samples

252 We compared the flammability (in terms of burn intensity, completeness of burn, and time-to-

253 ignition, respectively) of the dried samples with that of live samples of the same species that

254 was measured on five occasions under comparable fire weather conditions. We calculated the

255 change in flammability between live and dried samples by subtracting the flammability measure

256 of each live sample from that of its dried counterpart. We then used this derived variable as

257 response variable and employed Kruskal-Wallis to test whether the difference in flammability

258 between live and dried samples varied among vegetation groups.

259

260 Results

261 Live plant samples

262 Fire weather and live fuel moisture were not significantly correlated within any of the study

263 species (Supplemental Table S1). Increasing severity of fire weather significantly increased

264 flammability through increasing burn intensity, increasing completeness of burn, increasing the

265 likelihood of spontaneous ignition, and reducing time-to-ignition (Table 1, Fig. 1). Increasing live

266 fuel moisture significantly decreased burn intensity, completeness of burn, and the likelihood of

267 spontaneous ignition. Fuel load significantly increased burn intensity and time-to-ignition.

268 In considering vegetation groups, flammability was generally highest in IAPs,

269 intermediate in fynbos, and lowest in thicket (Table 1, Fig. 1). IAPs burnt at significantly higher

270 intensity than fynbos and thicket. IAPs and fynbos showed significantly higher ignitability

271 (shorter time-to-ignition and a greater likelihood of spontaneous ignition) than thicket.

272 Amongst the different fixed factors, vegetation groups consistently had the largest

273 influence (i.e. the largest scaled estimates; Table 1) on all flammability measures. Fire weather

274 had the second largest influence on ignitability, while live fuel moisture had the second largest

275 influence on burn intensity and completeness of burn.

Peer) reviewing PDF | (2020:04:48231:1:1:NEW 10 Sep 2020) 
The total variance in the flammability measures explained by the models was generally

277 low (24 - 40\%; conditional $R^{2}$ values, Table 1 ). The fixed factors combined explained less

278 variation (8 - 22\%; marginal $R^{2}$ values, Table 1 ) than species as random factor by itself (12 -

$27920 \%$ ), except in terms of spontaneous ignition where vegetation groups and fire weather were

280 most influential.

281

282 Dried plant samples

283 Drying out of samples under ambient conditions for two weeks resulted in an average reduction in 284 fuel moisture contents of approximately $30 \%$ (Fig. $2 \mathrm{~A}$ ), and the extent of this reduction did not 285 differ significantly among vegetation groups $\left(\mathrm{H}_{2}=1.4, \mathrm{p}=0.505\right)$. Dried samples exhibited increased 286 flammability compared to their live counterparts, i.e. an average increase in burn intensity of $115^{\circ} \mathrm{C}$; 287 an $11 \%$ increase in completeness of burn; and a 46 seconds reduction in time-to-ignition (Fig. 2 B 288 D). However, this differential response in flammability between dried and live samples was 289 comparable among the vegetation groups in terms of burn intensity $\left(\mathrm{H}_{2}=0.8, \mathrm{p}=0.666\right)$, 290 completeness of burn $\left(H_{2}=1.8, p=0.410\right)$, and time-to-ignition $\left(H_{2}=0.6, p=0.741\right)$.

291

\section{Discussion}

293 Effects of fuel moisture, fire weather, and fuel load on flammability

294 Fuel moisture content is widely regarded to be a major determinant of flammability in grassland, 295 shrubland and forested ecosystems with sufficient evidence of its dampening effects on fire behaviour and flammability (Bianchi and Defossé, 2015; Fares et al., 2017; Pausas and Paula, 2012). That is why several fire danger indices attempt to account for the moisture contents of dead and live fuels to improve fire danger forecasting (Chuvieco et al., 2004; Madula, 2013; Rothermel, 1983; Ruffault et al., 2018; Sirca et al., 2018). Although dead fuel moisture responds closely and rapidly to fire weather, the relation between live fuel moisture and fire weather is more complicated as it depends on plant physiology and medium- to long-term meteorological trends (Bianchi and Defossé, 2015; Bowman et al., 2014; Chuvieco et al., 2004; Nolan et al., 2016). Accordingly, live fuel moisture in this study was not significantly correlated with fire weather in any of the study species. Live fuel moisture did significantly (negatively) correlate to burn intensity and completeness of burn, but the magnitude of its influence on flammability relative to the other factors investigated was generally low. response of live plant moisture contents to fire weather suggests that the mechanism through 309 which fire weather enhances flammability may not be live fuel moisture. Other studies that have 
310 investigated fuel moisture-flammability relations (e.g., Bianchi et al., 2018) have not evidently

311 assessed the effects of fire weather or have manipulated fuel moisture through drying out of

312 fuels beyond natural levels of fluctuation in live fuels (Dimitrakopoulos and Papaioannou, 2001).

313 We argue that the importance of live fuel moisture for flammability of evergreen shrublands

314 rests on inter-specific and inter-vegetation type differences in fuel moisture contents (cf.

315 Chuvieco et al., 2004), rather than medium-term intra-specific fluctuation in live fuel moisture in

316 response to weather conditions. The incorporation of satellite-derived proxies for live fuel

317 moisture into fire danger indices is therefore unlikely to be useful in these systems. Although fire

318 weather increased all measures of flammability (and particularly ignitability), it was less

319 influential than vegetation groups (see scaled estimates in Table 1). The contribution of short-

320 term weather conditions to the severity of the 2017 Knysna fires was regarded to have been

321 secondary to that of the long-term drought preceding these fires that would have caused a

322 buildup of dead fuels (Kraaij et al., 2018). Fire weather is expected to increase in importance in

323 its effects on flammability if cognizance is taken of dry or dead fuels (see below) and when

324 considering stand level fire behaviour. Although flammability experiments at the plant shoot

325 scale are an improvement over those on excised leaves, and although results at the plant shoot

326 and whole-plant scale are often in agreement (Pausa and Moreira, 2012), the scale of

327 experimentation relative to stand or landscape level fire remains inadequate. For instance,

328 particular aspects of fire weather, such as wind speed, greatly influence wildfire spread and

329 spotting behavior (Forsyth et al., 2019). Such dynamics cannot be considered using the shoot-

330 level flammability methods used in the current study; this may lead to an underestimation of the

331 importance of fire weather on flammability and, by implication, fire behavior.

332 Fuel load had varying effects on flammability, depending on the measure considered; it

333 increased burn intensity, but reduced ignitability. These findings support other evidence for

334 positive correlations between the amount of biomass ( fuel load) that vegetation presents and

335 fire intensity or severity (Baeza et al., 2002; Keeley, 2009; Saura-Mas et al., 2010), but negative

336 correlations between fuel load and ignitability (Guijarro et al., 2002), the rate of spread

337 (Grootemaat et al., 2017) and completeness of burn (Kraaij et al., 2018; van Wilgen et al.,

338 1990). Such contrasting effects on the different aspects of flammability relate to variation in fuel

339 structural traits and emphasize the need to consider flammability in terms of its constituent

340 measures rather than treating it as a composite measure (Engber and Varner, 2012; Pausas et

341 al., 2012; Santana and Marrs, 2014).

$342 \quad$ Although live fuel moisture content, fire weather conditions, and fuel load had significant

343 effects on some of the flammability measures, these factors did not explain a large portion of 
344 variability in the flammability response. Species, which was assessed as a random factor, often

345 accounted for more variation in flammability than the fixed factors combined. This suggests

346 important species effects on flammability, which warrant more detailed investigation. Our

347 method of placing plant shoots horizontally on the barrel cavity grill with different amounts and

348 sizes of plant parts oriented towards the grill could have introduced additional variation in the

349 flammability response.

350

351 Vegetation group effects in relation to fire risk

352 Vegetation group comparisons showed that the flammability of IAPs exceeded that of thicket in

353 terms of all flammability measures and exceeded that of fynbos in terms of burn intensity. These

354 findings support claims (Forsyth et al., 2019; Stander, 2019) and other evidence (Brooks et al.,

355 2004; Kraaij et al., 2018; Richardson and Rejmánek, 2011) that invasions by alien plants can

356 add to the severity, intensity, and difficulty of control of wildfires. Fynbos and IAPs were more

357 ignitable than thicket, and thus present higher risks under moderate and high fire weather

358 conditions, whereas thicket presents lower risks under low and moderate fire weather

359 conditions. Accordingly, observations from the 2017 Knysna fires indicated that thicket only

360 becomes ignitable under very high or extreme fire weather conditions but may then burn at

361 intensities exceeding that in fynbos but not that of IAPs (Kraaij et al., 2018) presumably on

362 account of disparate fuel loads (Keeley, 2009; Mandle et al., 2011). In our study, there were no

363 significant differences between the flammability of fynbos and IAPs but completeness of burn

364 appeared to be the highest in fynbos. Kraaij et al. (2018) also observed that fynbos burnt more

365 completely than thicket and IAPs in the 2017 Knysna fires which suggests that the risk of

366 recurring fire will be lowest in fynbos for some period post-fire, whereas incomplete burning of

367 IAPs will not afford the same level of risk reduction shortly post-fire.

368

369

Simulated drought conditions

370 Extremely large and severe fires, including the 2017 Knysna fires, are often associated with

371 preceding droughts (Kraaij et al., 2018; Quinn, 1994; San-Miguel-Ayanz et al., 2013; Williams,

372 2013) and the resultant increase in dead fuels (Keeley, 2009). The extent and severity to which

373 thicket, normally regarded as a fire-resistant ( poorly ignitable) vegetation (Calitz et al., 2015;

374 Cowling and Potts, 2015), burnt in the 2017 Knysna fires was attributed to extreme fire weather

375 conditions and to the preceding severe drought (Kraaij et al., 2018). In this study, we confirmed

376 that the drying of fuels as a crude proxy for severe drought effects considerably increased

377 flammability. However, the magnitude of the increase in flammability in response to drying of 
378 fuels was consistent across vegetation groups. Flammability, and by implication fire risk, is thus

379 unlikely to increase disproportionately in one vegetation group compared to another under

380 extended drought unless the production of dead fuels due to drought would be disproportionate

381 among the vegetation groups. We concede that the proxy for drought conditions could not

382 realistically simulate all potential effects of drought on fuel modification and flammability, and in

383 particular on the dying off of fuels and resultant increase in litter component. Detailed

384 consideration of this aspect was beyond the scope of this study and warrants further

385 investigation. Given the low moisture contents of dead fuels, the ratio of dead to live fuels are

386 likely to be a useful indicator of fire risk in evergreen shrublands (Keeley, 2009). Proxies for this 387 ratio should, therefore, be sought for incorporation into fire danger indices.

\section{Conclusions}

390 Our experimental burning of shoots of 30 shrub species confirmed that fire weather, live fuel moisture, and fuel load have significant effects on flammability measures. However, vegetation group and species differences accounted for most of the variation in flammability. Flammability was generally highest in invasive alien plants, intermediate in fynbos, and lowest in thicket. The drying of plant shoots resulted in increases in flammability that were comparable among vegetation groups, implying that under drought conditions, fire risk should not increase disproportionately in one vegetation group compared to another, unless the production of dead fuels is disproportionate among vegetation groups.

398

399

400

401

402

403

404

405

406

\section{References}

408

409

410 manuscript.

\section{Acknowledgements}

We would like to extend gratitude to Phillip Frost for assisting with the Canadian Fire Weather Index calculations, and Tatenda Mapeto for making weather data available. Tiaan Strydom, Nicole Blignaut, Natasja Van Zyl, Marita Burger, Corne Brink, Siyabonga Sibisi, Gert Botha, Jooste Eileen and Herman Viviers assisted with specimen collection and flammability experiments. Constructive comments of two anonymous reviewers led to improvements to the

Archibald, S., Roy, D.P., van Wilgen, B.W., Scholes, R.J., 2008. What limits fire? An examination of drivers of burnt area in southern Africa. Global Change Biology 15, 613630. https://doi.org/10.1111/j.1365-2486.2008.01754.x 
411 Baard, J.A., Kraaij, T., 2014. Alien flora of the Garden Route National Park, South Africa. South

412

413

414

415

416

417

418

419

420

421

422

423

424

425

426

427

428

429

430

431

432

433

434

435

436

437

438

439

440

441

442

443

444

African Journal of Botany 94, 51-63. https://doi.org/10.1016/j.sajb.2014.05.010

Baeza, M.J., De Luís, M., Raventós, J., Escarré, A., 2002. Factors influencing fire behaviour in shrublands of different stand ages and the implications for using prescribed burning to reduce wildfire risk. Journal of Environmental Management 65, 199-208. https://doi.org/10.1006/jema.2002.0545

Bates, D.M., 2010. Ime4: Mixed-effects modeling with R, http:///me4.r-forge.r-project.org/book/, 470-474

Becker, R.A. 2018. Chambers, J.M., Wilks, A.R., (Eds.), The new S language.CRC Press.

Bianchi, L.O., Defossé, G.E., 2015. Live fuel moisture content and leaf ignition of forest species in Andean Patagonia, Argentina. International Journal of Wildland Fire 24, 340-348. https://doi.org/10.1071/WF13099

Bianchi, L.O., Oddi, F.J., Muñoz, M., Defossé, G.E., 2018. Comparison of leaf moisture content and ignition characteristics among native species and exotic conifers in Northwestern Patagonia, Argentina. Forest Science 1-12. https://doi.org/10.1093/forsci/fxy054

Bond, W.J., 1981. Vegetation gradients in the southern Cape mountains. MSc thesis, University of Cape Town.

Bond, W.J., 1997. Fire, in: Cowling, R.M., Richardson, D.M., Pierce, S.M. (Eds.), Vegetation of southern Africa. Cambridge University Press, Cambridge, United Kingdom, pp. 421-446.

Bond, W.J., Keeley, J.E., 2005. Fire as a global "herbivore": The ecology and evolution of flammable ecosystems. Trends in Ecology and Evolution 20, 387-394. https://doi.org/10.1016/j.tree.2005.04.025

Bond, W.J., Midgley, G.F., Woodward, F.I., 2003. What controls South African vegetation Climate or fire? South African Journal of Botany 69, 79-91. https://doi.org/10.1016/S0254-6299(15)30362-8

Bond, W.J., Midgley, J.J., 1995. Kill thy neighbour: An individualistic argument for the evolution of flammability. Oikos 73, 79-85. https://doi.org/10.2307/3545728

Bowman, D.M.J.S., French, B.J., Prior, L.D., 2014. Have plants evolved to self-immolate? Frontiers in Plant Science 5, 1-9. https://doi.org/10.3389/fpls.2014.00590

Brooks, M.L., Antonio, C.M.D., Richardson, D.M., Grace, J.B., Keeley, J.E., Ditomaso, J.M., Hobbs, R.J., Pellant, M., Pyke, D., Brooks, L., 2004. Effects of invasive alien plants on fire regimes. BioScience 54, 677-688.

Buhk, C., Meyn, A., Jentsch, A., 2007. The challenge of plant regeneration after fire in the Mediterranean Basin: Scientific gaps in our knowledge on plant strategies and evolution

Peer] reviewing PDF | (2020:04:48231:1:1:NEW 10 Sep 2020) 
445

446

447

448

449

450

451

452

453

454

455

456

457

458

459

460

461

462

463

464

465

466

467

468

469

470

471

472

473

474

475

476

477

478

of traits. Plant Ecology 192, 1-19. https://doi.org/10.1007/s11258-006-9224-2

Burger, N., Bond, W.J., 2015. Flammability traits of Cape shrubland species with different postfire recruitment strategies. South African Journal of Botany 101, 40-48. https://doi.org/10.1016/j.sajb.2015.05.026

Bradstock, R., 2010. A biogeographic model of fire regimes in Australia: current and future implications. Global Ecology and Biogeography 19, 145-158.

Byram, G.M., 1959. Combustion of forest fuels, in: Davis, K.P. (Ed.), Forest fire: control and use. McGraw-Hill, New York, pp. 61-89.

Calitz, W., Potts, A.J., Cowling, R.M., 2015. Investigating species-level flammability across five biomes in the Eastern Cape, South Africa. South African Journal of Botany 101, 32-39. https://doi.org/10.1016/j.sajb.2015.07.005

Campbell, B.M., Cowling, R.M., Bond, W.J., Kruger, F.J., Bands, D.P., Boucher, C., Moll, E.J., Taylor, H.C., van Wilgen, B.W., 1981. Structural characterization of vegetation in the Fynbos biome. South African National Scientific Programmes Report No 52.

Chuvieco, E., Aguado, I., Dimitrakopoulos, A.P., 2004. Conversion of fuel moisture content values to ignition potential for integrated fire danger assessment. Canadian Journal of Forest Research 34, 2284-2293. https://doi.org/10.1139/x04-101

Clarke, J.M., McCaig, T.N., 1982. Excised-leaf water retention capability as an indicator of drought resistance of triticum genotypes. Canadian Journal of Plant Science 62, 571578. https://doi.org/10.4141/cjps82-086

Cowling, R.M., Kirkwood, D., Midgley, J.J., Pierce, S.M., 1997. Invasion and persistence of birddispersed, subtropical thicket and forest species in fire-prone coastal Fynbos. Journal of Vegetation Science 8, 475-488.

Cowling, R.M., Potts, A.J., 2015. Climatic, edaphic and fire regime determinants of biome boundaries in the eastern Cape Floristic Region. South African Journal of Botany 101, 73-81. https://doi.org/10.1016/j.sajb.2015.03.182

Curran, T.J., Cubino, J.P., Buckely, H.L., Day, N.., Robin, P., 2017. Community- level flammability declines over 25 years of plant invasion in grasslands. Journal of Ecology 12, 1-37. https://doi.org/10.1111/ijlh.12426

Davies, K.W., Nafus, A.M., 2013. Exotic annual grass invasion alters fuel amounts, continuity and moisture content. International Journal of Wildland Fire 22, 353-358. https://doi.org/10.1071/WF11161

Deacon, H.., Jury, M.R., Ellis, F., 1992. Selective regime and time, in: Cowling, R.. (Ed.), The ecology of fynbos. Nutrients, fire and diversity. Oxford University Press, Cape Town, pp. 
479

480

481

482

483

484

485

486

487

488

489

490

491

492

493

494

495

496

497

498

499

500

501

502

503

504

505

506

507

508

509

510

511

512

6-20.

Dimitrakopoulos, A., Papaioannou, K., 2001. Flammability assessment of mediterranean forest fuels. Fire Technology 143-152. https://doi.org/10.1023/A

Dowdy, A.J., Mills, G. a, Finkele, K., De Groot, W., 2009. Australian fire weather as represented by the McArthur forest fire danger index and the Canadian forest fire weather index. The Centre For Australian Weather And Climate Research, Australia, 1-91.

Engber, E.A., Varner, J.M., 2012. Patterns of flammability of the California oaks: The role of leaf traits. Canadian Journal of Forest Research 42, 1965-1975. https://doi.org/10.1139/x2012-138

Fares, S., Bajocco, S., Salvati, L., Camarretta, N., Dupuy, J.L., Xanthopoulos, G., Guijarro, M., Madrigal, J., Hernando, C., Corona, P., 2017. Characterizing potential wildland fire fuel in live vegetation in the Mediterranean region. Annals of Forest Science 74. https://doi.org/10.1007/s13595-016-0599-5

Fernandes, P.M., Cruz, M.G., 2012. Plant flammability experiments offer limited insight into vegetation-fire dynamics interactions. New Phytologist 194, 606-609. https://doi.org/10.1111/j.1469-8137.2012.04065.x

Forsyth, G., Le Maitre, D., van den Dool, R., Walls, R., Pharoah, R., Fortune, G., 2019. The Knysna fires of 2017 : Learning from this disaster. CSIR, Stellenbosch University and Santam.

Geldenhuys, C.J., 1994. Bergwind fires and the location pattern of forest patches in the southern Cape landscape, South Africa. Journal of Biogeography 21, 49-62. https://doi.org/10.2307/2845603

Gill, A.M., Zylstra, P., 2005. Flammability of Australian forests. Australian Forestry 68, 87-93. https://doi.org/10.1080/00049158.2005.10674951

Grootemaat, S., Wright, I.J., van Bodegom, P.M., Cornelissen, J.H.C., 2017. Scaling up flammability from individual leaves to fuel beds. Oikos 126, 1428-1438. https://doi.org/10.1111/oik.03886

Guijarro, M., Hernando, C., Díez, C., Martínez, E., Madrigal, J., Lampin, C., Blanc, L., Colin, P., Pérez-Gorostiaga, P., Vega, J., Fonturbel, M., 2002. Flammability of some fuel beds common in the south-European ecosystems. Preceedings of the IV International Conference Forest Fire Research, 1-9.

Hastie, T.J., Pregibon, D., 1992. Generalized linear models, in: Chambers, J.M., Hastie, T.J. (Eds.), Statistical models, Chapter 6. Wadsworth \& Brooks/Cole.

Jaureguiberry, P., Bertone, G., Díaz, S., 2011. Device for the standard measurement of shoot 
513

514

515

516

517

518

519

520

521

522

523

524

525

526

527

528

529

530

531

532

533

534

535

536

537

538

539

540

541

542

543

544

545

546

flammability in the field. Austral Ecology 36, 821-829. https://doi.org/10.1111/j.14429993.2010.02222.x

Keeley, J.E., 2009. Fire intensity, fire severity and burn severity: A brief review and suggested usage. International Journal of Wildland Fire 18, 116-126. https://doi.org/10.1071/WF07049

Keeley, J.E., Bond, W.J., Bradstock, R.A., Pausas, J.G., Rundel, P.W., 2012. Fire in Mediterranean ecosystems. Ecology, evolution and management. Cambridge University. Keeley, J.E., Syphard, A.D., 2017. Different historical fire-climate patterns in California. International Journal of Wildland Fire 26, 253-268. https://doi.org/10.1071/WF16102

Kraaij, T., Baard, J.A., Arndt, J., Vhengani, L., van Wilgen, B.W., 2018. An assessment of climate, weather and fuel factors influencing a large, destructive wildfire in the Knysna region, South Africa. Fire Ecology 14, 1-12. https://doi.org/10.1186/s42408-018-0001-0

Kraaij, T., Cowling, R.M., van Wilgen, B.W., 2011. Past approaches and future challenges to the management of fire and invasive alien plants in the new Garden Route National Park. South African Journal of Science 107, 1-11. https://doi.org/10.4102/sajs.v107i9/10.633

Kraaij, T., Cowling, R.M., van Wilgen, B.W., 2013. Lightning and fire weather in eastern coastal fynbos shrublands: Seasonality and long-term trends. International Journal of Wildland Fire 22, 288-295. https://doi.org/10.1071/WF11167

Kraaij, T., van Wilgen, B.W., 2014. Drivers, ecology, and management of fire in fynbos, in: Allsopp, N., Colville, J.F., Verboom, G.A. (Eds.), Fynbos: Ecology, evolution, and conservation of a megadiverse region. pp. 45-66. https://doi.org/10.1093/acprof

Madula, A.R., 2013. Publication of the fire danger rating system for general information in terms of section 9 (1) on the National Veld and Forest Fire Act. Department of Agriculture, Forestry and Fisheries (DAFF)

Mandle, L., Bufford, J.L., Schmidt, I.B., Daehler, C.C., 2011. Woody exotic plant invasions and fire: Reciprocal impacts and consequences for native ecosystems. Biological Invasions 13, 1815-1827. https://doi.org/10.1007/s10530-011-0001-3

Moll, E.J., Campbell, B.M., Cowling, R.M., Bossi, L., Jarman, M.L., Boucher, C., 1984. A description of major vegetation categories in and adjacent to the fynbos biome. South African National Scientific Programmes Report No. 83. Graphic Arts Division of CSIR, South Africa.

Montenegro, G., Ginocchio, R., Segura, A., Keely, J.E., Gómez, M., 2004. Fire regimes and vegetation responses in two Mediterranean-climate regions. Ecological Research 77, 455-464. https://doi.org/10.4067/S0716-078X2004000300005 
547 Mucina, L., Rutherford, M.C., 2006. Southern Cape dune fynbos, in: Mucina, L., Rutherford,

548

549

550

551

552

553

554

555

556

557

558

559

560

561

562

563

564

565

566

567

568

569

570

571

572

573

574

575

576

577

578

579

580

M.C. (Eds.), The vegetation of South Africa, Lesotho and Swaziland. South African National Biodiversity Institute, Pretoria, pp. 144-145.

Murray, B.R., Hardstaff, L.K., Phillips, M.L., 2013. Differences in leaf flammability, leaf traits and flammability-trait relationships between native and exotic plant species of dry sclerophyll forest. PLoS ONE 8, 1-8. https://doi.org/10.1371/journal.pone.0079205

Mutch, R.W., 1970. Wildland fires and ecosystems - A hypothesis. Ecology 51, 1070-1051.

Noble, I.R., Gill, A.M., Bary, G.A. V, 1980. McArthur's fire-danger meters expressed as equations. Australian Journal of Ecology 5, 201-203. https://doi.org/10.1111/j.14429993.1980.tb01243.x

Nolan, R.H., Boer, M.M., de Dios, V.R., Caccamo, G., Bradstock, R.A., 2016. Large-scale, dynamic transformations in fuel moisture drive wildfire activity across southeastern Australia. Geophysical Research Letters 43, 4229-4238.

O'Hara, R.B., 2009. How to make models add up - a primer on GLMMs. Annales Zoologici Fennici 46, 124-137.

Pausas, J.G., Alessio, G.A., Moreira, B., Corcobado, G., 2012. Fires enhance flammability in Ulex parviflorus. New Phytologist 18-23.

Pausas, J.G., Bradstock, R.A., 2007. Fire persistence traits of plants along a productivity and disturbance gradient in mediterranean shrublands of south-east Australia. Global Ecology and Biogeography 16, 330-340. https://doi.org/10.1111/j.14668238.2006.00283.x

Pausas, J.G., Moreira, B., 2012. Flammability as a biological concept. New Phytologist 194, 610-613.

Pausas, J.G., Paula, S., 2012. Fuel shapes the fire-climate relationship: Evidence from Mediterranean ecosystems. Global Ecology and Biogeography 21, 1074-1082. https://doi.org/10.1111/j.1466-8238.2012.00769.x

Pierce, S.M., Cowling, R.M., 1984. Phenology of fynbos, renosterveld and subtropical thicket in the south eastern Cape. South African Journal of Botany 3, 1-16. https://doi.org/10.1016/S0022-4618(16)30074-2

Piñol, J., Terradas, J., Llored, F., 1998. Climate warming, wildfire hazard, and wildfire occurrence in coastal eastern Spain. Climatic Change 38, 345-375. https://doi.org/10.1016/S0140-6736(02)41344-X

Preston, G., 2017. Knysna fires : Five factors that produced the Perfect inferno. The Botanical Sociaty of South Africa. 
581 Quinn, R.D., 1994. The role of fire in Mediterranean-type ecosystems, in: Moreno, J.M., Oechel,

582

583

584

585

586

587

588

589

590

591

592

593

594

595

596

597

598

599

600

601

602

603

604

605

606

607

608

609

610

611

612

613

614 W.C. (Eds.), Animals, fire, and vertebrate herbivory in Californian chaparral and other Mediterranean-type ecosystems. Springer-Verlag, New York, pp. 46-78. https://doi.org/10.1007/978-1-4613-8395-6_4

Radeloff, V.C., Hammer, R.B., Stewart, S.I., Fried, J.S., Holcomb, S.S., McKeefry, J.F., 2005. The wildland-urban interface in the United States. Ecological Applications 15, 799-805. https://doi.org/10.1111/jofo.

Richardson, D.M., Rejmánek, M., 2011. Trees and shrubs as invasive alien species - a global review. Diversity and Distributions 17, 788-809. https://doi.org/10.1111/j.14724642.2011.00782.x

Richardson, D.M., van Wilgen, B.W., 2004. Invasive alien plants in South Africa: How well do we understand the ecological impacts? South African Journal of Science 100, 45-52. https://doi.org/10.2307/2405025

Rothermel, R.C., 1983. How to predict the spread and intensity of forest and range fires, USDA Forest Service, International Forest and Range Experiment Station, General Technical Report INT - 143. Forest Service General Technical Report INT-143. https://doi.org/U.S

Ruffault, J., Martin-StPaul, N., Pimont, F., Dupuy, J.-L., 2018. How well do meteorological drought indices predict live fuel moisture content (LFMC)? An assessment for wildfire research and operations in Mediterranean ecosystems. Agricultural and Forest Meteorology 262, 391-401. https://doi.org/10.1016/j.agrformet.2018.07.031

San-Miguel-Ayanz, J., Moreno, J.M., Camia, A., 2013. Analysis of large fires in European Mediterranean landscapes: Lessons learned and perspectives. Forest Ecology and Management 294, 11-22. https://doi.org/10.1016/j.foreco.2012.10.050

Santana, V.M., Marrs, R.H., 2014. Flammability properties of British heathland and moorland vegetation: Models for predicting fire ignition. Journal of Environmental Management 139, 88-96. https://doi.org/10.1016/j.jenvman.2014.02.027

Saura-Mas, S., Paula, S., Pausas, J.G., Lloret, F., 2010. Fuel loading and flammability in the Mediterranean Basin woody species with different post-fire regenerative strategies. International Journal of Wildland Fire 19, 783-794. https://doi.org/10.1071/WF09066

Scott, D.F., Versfeld, D.B., Lesch, W., 1998. Erosion and sediment yield in relation to afforestation and fire in the mountains of the Western Cape Province, South Africa. South African Geographical Journal 80, 52-59. https://doi.org/10.1080/03736245.1998.9713644

Sirca, C., Salis, M., Arca, B., Duce, P., Spano, D., 2018. Assessing the performance of fire 
615

616

617

618

619

620

621

622

623

624

625

626

627

628

629

630

631

632

633

634

635

636

637

638

639

640

641

642

643

644

645

646

647

648

danger indexes in a Mediterranean area. IForest 11, 563-571.

https://doi.org/10.3832/ifor2679-011

Snyder, J.R., 1984. The role of fire: Mutch ado about nothing? Oikos 43, 404-405.

Stander, Y., 2019. Call for action on cause of the fires. Knysna-Plett Herald.

Strydom, T., Kraaij, T., Cowling, R.M., Difford, M., submitted. Fire intensity does not govern survival and resprouting vigour of subtropical dune thicket in the south eastern Cape Floristic Region. Plant Ecology.

Syphard, A.D., Keeley, J.E., Pfaff, A.H., Ferschweiler, K., 2017. Human presence diminishes the importance of climate in driving fire activity across the United States. Proceedings of the National Academy of Sciences 114, 13750-13755. https://doi.org/10.1073/pnas.1713885114

Teie, W.C., 2009. Fire manager's handbook on veld and forest fires : Strategy, Tactics and Safety, 2nd ed. South African Institute of Forestry.

The Plant List, 2013. Version 1.1. Published on the Internet; http://www.theplantlist.org/ (accessed 1st May 2018)

Turco, M., Von Hardenberg, J., AghaKouchak, A., Llasat, M.C., Provenzale, A., Trigo, R.M., 2017. On the key role of droughts in the dynamics of summer fires in Mediterranean Europe. Scientific Reports 7, 1-10. https://doi.org/10.1038/s41598-017-00116-9

Van Wagner, C.E., Forest, P., 1987. Development and structure of the Canadian forest fireweather index system. Forestry Technical Report, Canadian Forest Service, Chalk River, Ontario.

van Wilgen, B.W., 1984. Fire climates in the southern and Western Cape province and their potential use in fire control and management. South African Journal of Science 80, 358362.

van Wilgen, B.W., Fill, J.M., Baard, J., Cheney, C., Forsyth, A.T., Kraaij, T., 2016. Historical costs and projected future scenarios for the management of invasive alien plants in protected areas in the Cape Floristic Region. Biological Conservation 200, 168-177. https://doi.org/10.1016/j.biocon.2016.06.008

van Wilgen, B.W., Higgins, K.B., Bellstedt, D.U., 1990. The role of vegetation structure and fuel chemistry in excluding fire from forest patches in the fire-prone fynbos shrublands of South Africa. Journal of Ecology 78, 210-222.

Williams, J., 2013. Exploring the onset of high-impact mega-fires through a forest land management prism. Forest Ecology and Management 294, 4-10.

https://doi.org/10.1016/j.foreco.2012.06.030

Peer] reviewing PDF | (2020:04:48231:1:1:NEW 10 Sep 2020) 
649 Yebra, M., Scortechini, G., Yoon, H.-J., Badi, A., Beget, M.E., Boer, M., Bradstock, R., 650 Chuvieco, E., Donson, M., Dennison, P., Di Bella, C.M., Forsyth, G., Frost, P., Garcia,

651 M., Jolly, W.M., Kraaij, T., Martin, M.P., Mouillot, F., Mewnham, G., Nolan, R.H.,

652 Pellizzaro, G., Qi, Y., Quan, X., de Dios, V.R., Riano, D., Roberts, D., Sow, M., Ustin, S.,

653 2019. Globe-LFMC, a global plant water status database for vegetation ecophysiology

654 and wildfire applications. Scientific Data - Nature 6, 155 https://doi.org/10.1038/s41597655 019-0164-9 


\section{Table $\mathbf{1}$ (on next page)}

Output of generalized linear mixed-effects models and logistic regression model that assessed flammability in terms of burn intensity, completeness of burn, time-to-ignition and spontaneous ignition.

Fixed factors included in the generalized linear mixed-effects models (gaussian family, identity function; details in Supplementary 2) and logistic regression model (binomial family, logit link function) were fire weather, fuel moisture, fuel load, and vegetation groups (IAPs, invasive alien plants; Fyn, fynbos; and Thi, thicket), while species was included as a random factor.

Significance codes: $* p<0.05,{ }^{* *} p<0.01, * * * p<0.001$

${ }^{a}$ Chisq statistics and significance levels were obtained from deviance tables (Type II Wald chi-square tests; details in Supplemental Table S3).

${ }^{\mathrm{b}}$ Scaled estimates were derived from incorporating the scale function in the generalized linear mixed-effects models and logistic regression model.

${ }^{c} R^{2}$ values were derived using the r.squared GLMM function, where conditional $R^{2}$ indicates the proportion of variance explained by fixed and random factors combined, marginal $R^{2}$ indicates the proportion of variance explained by fixed factors alone and $R^{2}(1 \mid S p e c i e s)$ indicates variance explained by the random factor alone. 


\begin{tabular}{|c|c|c|c|c|c|c|c|c|c|c|c|c|}
\hline \multirow[t]{2}{*}{ Factors } & \multicolumn{3}{|c|}{ Burn intensity } & \multicolumn{3}{|c|}{ Completeness of burn } & \multicolumn{3}{|c|}{ Time-to-ignition } & \multicolumn{3}{|c|}{ Spontaneous ignition } \\
\hline & Estimate & Chisq $^{a}$ & $\begin{array}{c}\text { Scaled } \\
\text { estimate } \\
\mathrm{b}\end{array}$ & Estimate & Chisq $^{a}$ & $\begin{array}{l}\text { Scaled } \\
\text { estimate } \\
\mathrm{b}\end{array}$ & Estimate & Chisq $^{a}$ & $\begin{array}{l}\text { Scaled } \\
\text { estimate } \\
\mathrm{b}\end{array}$ & Estimate & $\underset{a}{\text { Chisq }}$ & $\begin{array}{l}\text { Scaled } \\
\text { estimat } \\
\mathrm{b}\end{array}$ \\
\hline Fire weather & 0.0007 & $4.1^{*}$ & 0.06731 & 0.1300 & $11.0 * * *$ & 0.1175 & -0.0339 & $21.0 * * *$ & 0.19471 & 0.0650 & $\begin{array}{c}23.8 \\
* * *\end{array}$ & 0.667 \\
\hline Fuel moisture & -0.0015 & $4.4^{*}$ & 0.11524 & -0.1616 & $4.6^{*}$ & 0.1225 & 0.0271 & 2.8 & 0.09747 & -0.0379 & $4.5^{*}$ & 0.3265 \\
\hline Fuel load & 0.0004 & 5.6 * & 0.10090 & -0.0180 & 1.1 & 0.0477 & 0.0121 & 9.3 * & 0.16529 & -0.0063 & 2.6 & 0.1900 \\
\hline Veg group [IAP and Fyn] & -0.0427 & \multirow{2}{*}{$8.1 *$} & 0.39141 & -1.1895 & \multirow{2}{*}{5.7} & 0.1048 & -0.7575 & \multirow{2}{*}{$9.6^{* *}$} & 0.36388 & 0.2156 & \multirow{2}{*}{$\begin{array}{c}16.3 \\
\star * *\end{array}$} & 0.215 \\
\hline Veg group [IAP and Thi] & -0.0648 & & 0.59446 & -5.2832 & & 0.4657 & 0.8838 & & 0.42458 & -1.5563 & & 1.556 \\
\hline Conditional $\mathrm{R}^{2 \mathrm{c}}$ & & 0.2961 & & & 0.2442 & & & 0.3983 & & & 0.3459 & \\
\hline Marginal $\mathrm{R}^{2 \mathrm{c}}$ & & 0.0942 & & & 0.0798 & & & 0.1935 & & & 0.2258 & \\
\hline $\mathrm{R}^{2}(1 \mid \text { Species })^{\mathrm{c}}$ & & 0.2019 & & & 0.1644 & & & 0.2048 & & & 0.1201 & \\
\hline
\end{tabular}

2 
Figure 1

Predicted effects of fixed factors on the flammability measures, (A - D) burn intensity, ( $E$ - H) completeness of burn, $(\mathrm{I}-\mathrm{L})$ time-to-ignition, and the probability of $(\mathrm{M}-\mathrm{P})$ spontaneous ignition.

Fixed factors were fire weather, fuel moisture, fuel load, and vegetation group (IAPs, invasive alien plants; Fyn, fynbos; and Thi, thicket). The effects shown here were based on the model outputs shown in Table 1 (shaded bands depict standard errors and whiskers show 95\% confidence intervals).
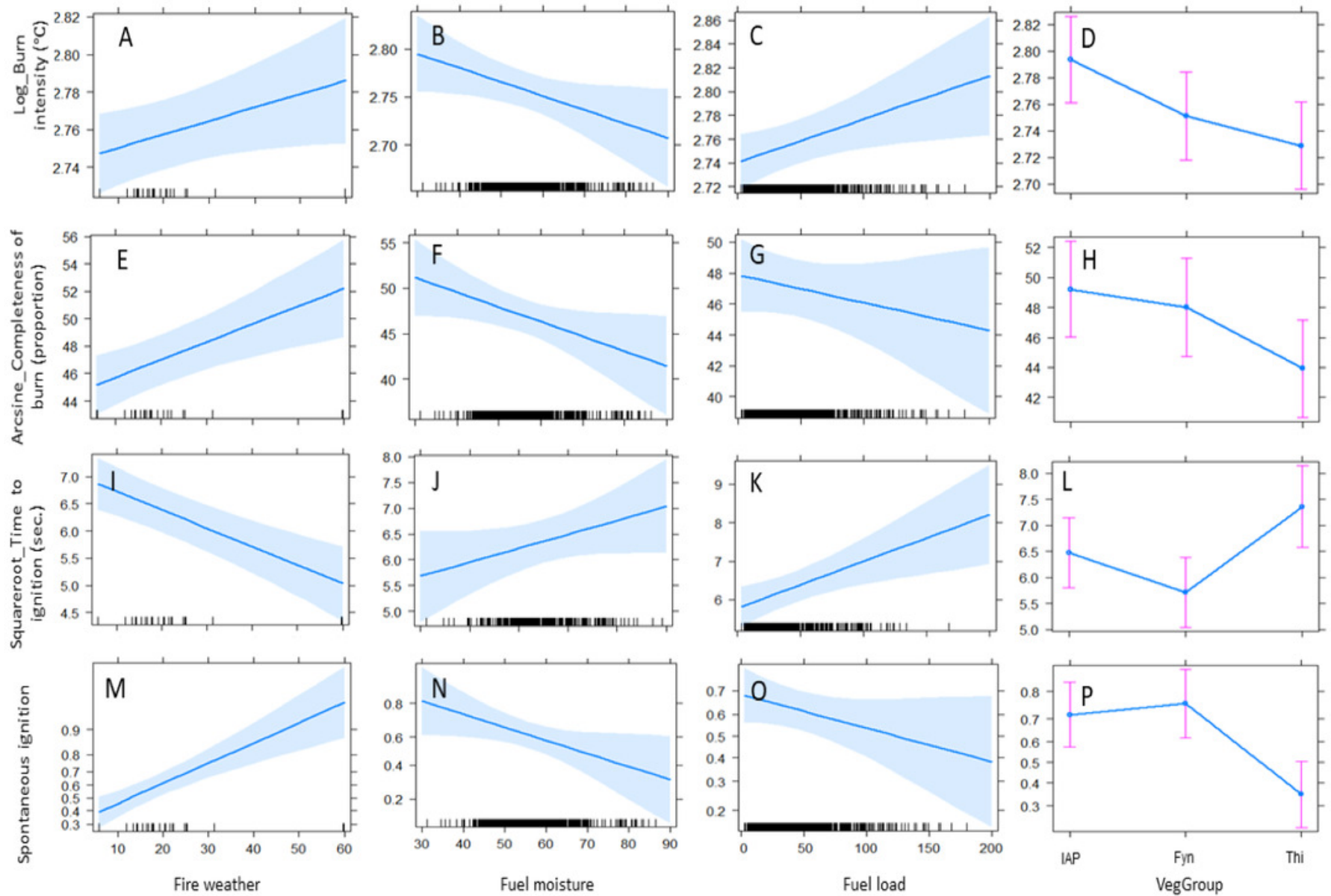


\section{Figure 2}

The change $(\Delta)$ between live and dried samples in (A) fuel moisture, (B) burn intensity, (C) completeness of burn, and (D) time-to-ignition, compared among vegetation groups.

Live and dried samples were of the same species under comparable fire weather conditions. Vegetation groups were IAPs, invasive alien plants; Fyn, fynbos; and Thi, thicket. Medians (lines), 25-75 quantile ranges (boxes), $1.5 *$ interquartile ranges (whiskers), and outliers (dots) are shown. 


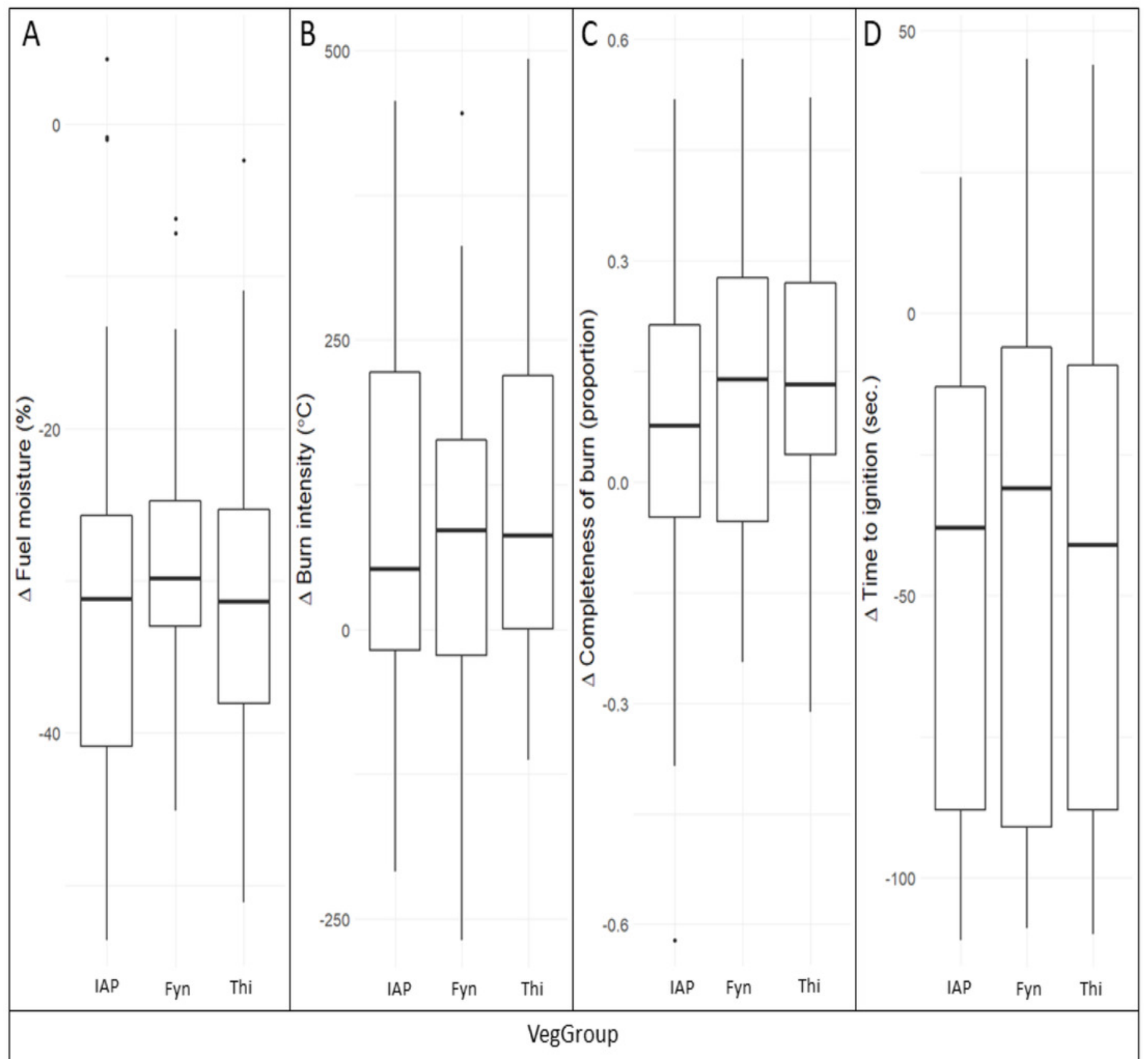

